\title{
ISPA Pada Balita Di Desa Samba Danum UPTD Puskesmas Tumbang Samba Kecamatan Katingan Tengah
}

\author{
Indra Fransisco, Amd. Kep, Devi Angeliana Kusumaningtiar, SKM, MPH, Ira Marti \\ Ayu, SKM, M.Epid, Ahmad Irfandi, SKM, MKM \\ Program Studi Kesehatan Masyarakat, Fakultas Ilmu-ilmu Kesehatan, Universitas Esa \\ Unggul
}

\begin{abstract}
Abstrak
Latar Belakang:Acute Respiratory Infections (ARI) arise due to infection with agents with human to human transmission and symptoms can appear in a short time. Menurut hasil laporan bulanan yang didapatkan dari Puskesmas Tumbang Samba jumlah penderita ISPA pada 2 bulan terakhir mengalami peningkatan dari 22,6\% menjadi 30,1\%. Berdasarkan kasus yang terjadi pada balita di Puskesmas Tumbang Samba jumlah kunjungan rata-rata pasien ISPA sebanyak 276 balita setiap tahun. Studi ini dilakukan untuk menilai faktor-faktor apa saja yang berhubungan dengan kejadian penyakit ISPA pada balita di Desa Samba Danum Wilayah Kerja UPTD Puskesmas Tumbang Samba Kecamatan Katingan Tengah Tahun 2021.

Metode: Studi cross sectional dilakukan pada Desember 2020 sampai Januari 2021 dengan sampel 165 responden yang dipilih secara puposive sampling. Kuesioner digunakan untuk mengumpulkan variabel umur, status gizi, status imunisasi dan ISPA. Data dianalisis bivariat dengan uji Chi Square.

Hasil: Hasil penelitian ini menemukan sebanyak 91 balita (55.2\%) mengalami ISPA. Proporsi tertinggi ditemukan pada umur balita (21.8\%), balita gizi baik (67.9\%), imunisasi tidak lengkap (66,1\%). Hasil Chi Square menunjukan terdapat hubungan antara umur dan status imunisasi dengan kejadian ISPA, sedangkan status gizi tidak terdapat hubungan dengan kejadian ISPA.

Kata kunci: Kejadian ISPA, Umur, Status Gizi, Status Imunisasi
\end{abstract}

\section{ARI in Toddlers in Samba Danum Village UPTD Tumbang Samba Health Center, Central Katingan District}

\begin{abstract}
Background: Acute Respiratory Infection or ARI is a respiratory tract disease caused by infectious agent, and is transmitted from human to human with symptoms usually appearing quickly. According to the results of monthly reports obtained from the Tumbang Samba Public Health Center, the number of patients with ARI in the last 2 months has increased from $22.6 \%$ to $30.1 \%$. Based on cases that occurred in toddlers at the Tumbang Samba Health Center, the average number of visits for ARI patients was 276 toddlers every year. This study was conducted to assessed related factors associated with the incidence of ARI in children under five in Samba Danum Village, the Working Area of the UPTD Puskesmas Tumbang Samba, Central Katingan District in 2021. Method:The cross sectional study was conducted from December 2020 to January 2021 with a sample of 165 respondents who were selected by purposive sampling. Questionnaires were used to collect variables of age, nutritional status, immunization status and ARI. Data were analyzed bivariate with Chi Square test.

Result:The results of this study found that 91 children under five (55.2\%) had ARI. The highest proportion was found at the age of toddlers (21.8\%), well-nourished children (67.9\%), incomplete immunization (66.1\%). Chi Square results show that there is a relationship between age and immunization status with the incidence of ARI, while nutritional status has no relationship with the incidence of ARI.
\end{abstract}

Keywords: ARI, age, nutritional status, immunization status

Korespondensi: Devi Angeliana

Email: deviangeliana@esaunggul.ac.id 


\section{PENDAHULUAN}

Infeksi Saluran Pernafasan Akut (ISPA) merupakan penyakit infeksi yang menyerang saluran pernpasan atas atau bawah, dapat menular, dapat tanpa gejala dan berpotensi mematikan ${ }^{1,2}$. Menurut World Health Organization kematian balita masih menjadi masalah kesehatan yang menjadi perhatian karen sekitar lima belas ribu anak meninggal per hari. Sedangkan selama tahun 2017, sebanyak 5,4 juta balita meninggal ${ }^{3}$. Oleh karena itu, ISPA menyumbang 16\% kematian anak $<5$ tahun. Prevalensi ISPA berdasarkan Riset Kesehatan Dasar (Riskesdas) tahun 2018 sebesar 9,3\%. Prevalensi tertinggi secara berturut-turut berdasarkan provinsi yaitu Nusa Tenggara Timur $(15,4 \%)$, Papua $(13,1 \%)$, Papua Barat (12,3\%), Banten (12,3\%), dan Bengkulu (11,8\%). Menurut kelompok umur, prevalensi tertinggi ada pada kelompok 1-4 tahun $(13,7 \%)$, tetapi tidak berbeda antara lakilaki dan perempuan. ISPA ditemukan terjadi pada penduduk dengan kuintil indeks kepemilikan terbawah dan menengah bawah ${ }^{4}$.

Angka ISPA di Kalimantan Tengah sendiri juga cukup tinggi. Berdasarkan Data Dinas Kesehatan Provinsi Kalimantan Tengah 2019, angka penderita ISPA di Kalimantan Tengah yaitu mecapai 9.000 jiwa $^{5}$. ISPA sering dilaporkan berkaitan dengan faktor lingkungan, faktor individu dan faktor perilaku. Faktor lingkungan seperti adanya polutan udara yang ada di dalam rumah, kondisi fisik rumah dan kepadatan hunian rumah. Lalu ada faktor individu anak seperti umur anak, berat badan lahir, status gizi dan status imunisasi. Faktor perilaku seperti kebiasaan merokok anggota keluarga ${ }^{6}$.

Penelitian terdahulu menemukan keterkaitan status imunisasi dengan kejadian penyakit ISPA pada balita ${ }^{7}$. Balita yang status imuniasinya tidak lengkap memiliki risiko 2,375 kali lebih besar dan mudah untuk mengalami ISPA dibandingkan anak balita yang status imunisasinya lengkap. Faktor lain yang ditemukan oleh peneliti lain yaitu status gizi, BBLR, dan ventilasi ${ }^{8}$. Pemberian imunisasi dasar dan cakupan imunisasi juga berperan dalam terjadinya ISPA balita ${ }^{9,10}$.

UPTD Kecamatan Katingan Tengah Puskesmas Tumbang Samba Terletak di Alamat Desa Tumbang Samba, Kecamatan Katingan Tengah, Kabupaten Katingan, Kalimantan Tengah. UPTD Puskesmas
Tumbang Samba membawahi 16 desa. Menurut laporan bulanan pada penanganan balita penderita infeksi saluran pernafasan atas akut (ISPA) yang naik dalam 6 bulan terakhir tahun 2020, data yang diperoleh dari UPTD Puskesmas Tumbang Samba total angka kejadian penyakit ISPA pada balita (12-49 bulan) pada bulan Januari sampai dengan bulan Juni 2020 sebanyak 81,6\% kasus. Prevalens kasus balita penderita ISPA yang mengalami peningkatan pada tiap bulan di UPTD Puskesmas samba Danum. Menurut laporan bulanan Puskesmas Tumbang Samba jumlah penderita ISPA balita di bulan mei sebanyak $18,1 \%$ dengan jumlah 21 kasus dan jumlah 116 kunjungan, dan bulan juni sebanyak 20,3\% dengan jumlah 28 kasus dengan total dengan jumlah 138 kunjungan. Berdasarkan kasus yang terjadi pada balita di Puskesmas Tumbang Samba jumlah kunjungan rata-rata pasien ISPA sebanyak 276 balita setiap tahun, dan dampak yang terjadi pada balita mengalami tidak nafsu makan yang berkurang dan berat badan menurun pada balita. Data tersebut menunjukan terjadinya peningkatan kasus ISPA pada balita di Puskesmas Samba Danum Tahun 2020. Untuk itu, penulis tertarik melakukan penelitian dengan judul "Faktor-Faktor yang Berhubungan dengan Kejadian Penyakit ISPA Pada Balita 12-49 bulan di Desa Samba Danum Wilayah Kerja UPTD Puskesmas Tumbang Samba Kecamatan Katingan Tengah Tahun 2020".

\section{METODE}

Studi cross sectional ini telah lolos kaji
etik dengan nomor 27/PRODI/KESMAS/UEU/IV/2021. Sampel yaitu sebagian balita berusia $12-59$ bulan yang berkunjung ke Puskesmas Samba Danum yang dipilih secara purposive sampling dengan kriteria inklusi yang membawa KMS dan pasien balita yang sedang berobat di Puskesmas Samba Danum dan bersedia menjadi responden pada bulan Desember 2020 - Januari 2021 sedangkan kriteria eksklusi adalah pasien yang mempunyai riwayat penyakit pernapasan misalnya asma. Total sampel penelitian yaitu dengan mengunakan total populai sebanyak 165 orang. Sedangkan untuk variabel independen yang diteliti umur, 
status gizi, status imunisasi, sedangkan variabel dependen kejadian ISPA pada Balita di UPTD Puskesmas Samba Danum. Analisis data univariat dan bivariat yang digunakan adalah uji Chi Square.

\section{HASIL}

Analisis terhadap distribusi proporsi dan frekuensi didapatkan gambaran dari masingmasing variabel yang disajikan pada Tabel 1 .

\begin{tabular}{|c|c|c|}
\hline Faktor-faktor & Frekuensi & $\%$ \\
\hline \multicolumn{3}{|l|}{ Kejadian ISPA } \\
\hline ISPA & 91 & 55,2 \\
\hline Tidak ISPA & 74 & 44,8 \\
\hline \multicolumn{3}{|l|}{ Umur } \\
\hline Bereiko & 129 & 78,2 \\
\hline Tidak Beresikso & 36 & 21.8 \\
\hline Status Gizi & & \\
\hline
\end{tabular}

\begin{tabular}{lcc}
\hline Gizi Buruk & 53 & 32,1 \\
Gizi Baik & 112 & 67,9 \\
Status Imunisasi & & \\
Tidak Lengkap & 109 & 66,1 \\
Lengkap & 56 & 33,9 \\
\hline
\end{tabular}

Hasil analisis terhadap kejadian ISPA balita diketahui bahwa dari 165 responden, proporsi tertinggi terdapat pada balita yang mengalami ISPA sebanyak $91 \quad(55.2 \%)$, Proporsi tertinggi terdapat pada balita yang umur beresiko sebanyak $129(78.2 \%)$, balita yang mengalami gizi baik sebanyak 112 $(67.9 \%)$, terdapat pada balita yang status imunisasinya tidak lengkap sebanyak 109 $(66,1 \%)$.

Uji Chi Square dilakukan pada variabel umur, status imunisasi, status gizi untuk menilai hubungan dengan kejadian ISPA di Puskesmas Samba Danum.

Tabel 2. Analisis hubungan kejadian ISPA balita dengan umur, status gizi, status imunisasi.

\begin{tabular}{|c|c|c|c|c|c|c|}
\hline \multirow[t]{3}{*}{ Variabel } & \multicolumn{4}{|c|}{ Kejadian ISPA } & \multirow{3}{*}{$\begin{array}{c}\text { Nilai } \\
\text { p-value }\end{array}$} & \multirow[t]{3}{*}{ PR 95\% CI } \\
\hline & \multicolumn{2}{|c|}{ ISPA } & \multicolumn{2}{|c|}{ Tidak ISPA } & & \\
\hline & $\mathbf{N}$ & $\%$ & $\mathbf{N}$ & $\%$ & & \\
\hline \multicolumn{7}{|l|}{ Umur } \\
\hline Beresiko & 78 & 60,5 & 51 & 39,5 & $0,016^{*}$ & $1,674(1,061-2,643$ \\
\hline Tidak Beresiko & 13 & 36,1 & 23 & 63,9 & & \\
\hline \multicolumn{7}{|l|}{ Status Gizi } \\
\hline Buruk & 27 & 50,9 & 26 & 49,1 & 0,562 & $0,892(0,654-1,214$ \\
\hline Baik & 64 & 57,1 & 48 & 42,9 & & \\
\hline \multicolumn{7}{|l|}{ Status Imunisasi } \\
\hline Tidak Lengkap & 68 & 62,4 & 41 & 37,6 & $0,015^{*}$ & $1,519(1,075-2,147$ \\
\hline Lengkap & 23 & 41,1 & 33 & 58,9 & & \\
\hline
\end{tabular}

Berdasarkan Tabel 2 didapatkan hasil adanya hubungan yang bermakna antara status umur dengan kejadian penyakit ISPA Prevelens Ratio (PR) dengan derajat kepercayaan $95 \%$, yang berarti balita yang umur beresiko 12-36 bulan lebih beresiko 1,674 kali terkena ISPA dibandingkan dengan balita umur 37-59 bulan. Namun ditemukan status gizi dengan kejadian penyakit ISPA tidak ada hubungan secara statistic. Nilai PR yang didapatkan berarti anak balita yang memiliki status gizi baik lebih bersifat protektif terhadap ISPA. Status imunisasi ditemukan berhubungan dengan ISPA. Nilai PR 1,519 (1,075-2,147) yang berarti balita yang memiliki status imunisasinya tidak lengkap beresiko 1,519 kali terkena penyakit
ISPA dibandingkan dengan balita yang telah memiliki status imunisasi lengkap.

\section{PEMBAHASAN \\ Umur terhadap ISPA Balita}

Berdasarkan analisis terhadap 165 responden di Puskesmas Samba Danum, didapatkan proporssi tertinggi pada balita umur balita yang beresiko lebih banyak mengalami ISPA sebesar 78 (60,5\%). Sedangkan proporsi tertinggi pada umur balita tidak beresiko lebih banyak tidak mengalami ISPA yaitu sebesar $13(36,1 \%)$.

Penelitian ini menemukan adanya hubungan yang bermakna antara status umur dengan kejadian penyakit ISPA. Prevelens Ratio (PR) dengan derajat kepercayaan 95\%, yang berarti balita yang umur beresiko 12-36 
bulan lebih beresiko 1,674 kali terkena ISPA dibandingkan dengan balita umur 37-59 bulan. Hasil ini konsisten dengan penelitian terdahulu yang juga menemukan umur sebagai faktor risiko ISPA balita (11).

Anak di bawah usia setahun juga dikategorikan sebagai balita, tetapi faal tubuhnya berbeda dengan anak-anak usia lebih dari setahun. Kelompok umur ini sangat rentan terhadap berbagai penyakit infeksi sehingga dibutuhkan zat gizi yang lebih tinggi dibandingkan usia lebih dari setahun. Oleh karena itu, kelompok usia kurang dari setahun kemungkinan mengalami ISPA lebih tinggi dibandingkan balita usia lebih dari setahun (12). Berdasarkan karakteristiknya, balita 1-5 tahun terbagi menjadi 2 kelompok yaitu usia 13 tahun yang disebut sebagai konsumen pasif dan usia 3-5 disebut sebagai konsumen aktif (13).

Penelitian ini menemukan peran umur balita dengan kejadian penyakit ISPA karena balita yang umur beresiko belum meningkat kekebalan tubuh dan balita dengan umur beresiko (12-36 bulan) lebih banyak dibandandingkan umur tidak beresiko (37-59 bulan) pada saat penelitian. Kejadian ISPA pada balita usia berisiko sejalan dengan teori bahwa balita yang umur beresiko lebih rentan terhadap berbagai penyakit, upaya yang dapat meningkat imun balita adalah dengan memberikan asupan ASI, vitamin C dan E, asupan mengandung zat besi, dan komsumsi asupan omega 3 yang mampu memperkuat imun balita serta menjaga kinerja system kekebalan tubuh balita.

Hal yang membuat balita $<37$ bulan banyak lebih banyak datang ke puskesmas dikarenakan balita yang umur beresiko (12-36 bulan)terkena ISPA diberikan pengarahan serta edukasi saat pemeriksaan untuk lebih sering datang ke puskesmas dan dilakukan pemeriksaan rutinuntuk mendapatkan jadwal pelayanan kesehatan pengobatan ISPA balita, serta untuk mendapatkan edukasi untuk orang tua balita terkait tumbuh kembang balita dan perawatan balita yang beresiko ISPA di rumah secara mandiri. Maka dari itu balita dengan umur $<37$ bulan lebih sering datang berkunjung ke puskesmas dan melakukan pemeriksaan dibandingkan balita dengan umur $>36$ bulan.

Sebaiknya program puskesmas selanjutnya dalam memberikan makanan tambahan untuk terus dilanjutkan dan juga ditambahkan dengan nutrisi yang seimbang dikarenakan untuk dapat meningkatkan kekebalan tubuh balita serta untuk meningkatnya imunitas pada balita dan juga disarankan agar dilakukan pemeriksaan rutin supaya dapat diketahui lebih awal jika balita teridentifikasi ISPA atau penyakit lainnya sehingga dapat penanganan lebih awal dari pihak puskesmas setempat, serta disarankan juga memberikan edukasi untuk peran ibu dalam menjaga balitanya di umur yang masih rawan dengan berbagai macam penyakit, dan diharapkan pihak puskesmas ataupun dari petugas posyandu untuk lebih sering berkunjung ke daerah-daerah perkampungan yang jauh dan kurang mendapatkan akses untuk bisa rutin datang untuk melakukan pemeriksaan ke puskesmas ataupun posyandu, serta memberitahukan juga kepada ibu dari balita yang kurang aktif melakukan pemeriksaan di puskesmas sesuai dengan edukasi jadwal yang telah diberitahukan kepada masing-masing dari ibu balita yang umur beresiko rawan terkena ISPA supaya lebihaktif lagi dan giat untuk datang ke puskesmas ataupun posyandu untuk melakukan pemeriksaan secara rutin bagi balita yang umur beresiko rawan terkena ISPA sesuai dengan edukasi jadwal yang telah ditentukan, dikarenakan masih banyak dari ibu-ibu dari balita yang kurang aktif ataupun giat dalam melakukan pemeriksaan secara rutin terhadap balitanya dengan alasan sibuk bekerja maupun sarana transportasi untuk datang ke puskesmas dan posyandu karena tinggal di daerah perkampungan yang jauh.

\section{Status Gizi terhadap ISPA Balita}

Studi ISPA pada balita ini menemukan proporsi tertinggi pada balita yang memiliki status gizi kurang lebih banyak mengalami penyakit ISPA sebesar 27 (50,9\%). Status gizi baik lebih banyak mengalami ISPA sebesar $57,1 \%$. Namun tidak ditemukan hubungan yang bermakna antara status gizi dengan kejadian penyakit ISPA. Nilai PR justru menemukan balita yang memiliki status gizi baik bersifat protektif. Temuan ini sejalan dengan penelitian sebelumnya yang juga menemukan tidak terdapat hubungan antara status gizi dengan kejadian ISPA pada anak balita ((14).

Balita dengan kondisi gizi yang kurang akan lebih mudah terserang penyakit ISPA karena faktor daya tahan tubuh yang 
kurang. Penyakit infeksi menyebabkan balita penurunan nafsu makan dan kekurangan gizi. Kondisi tersebut dapat mengarahkan pada "ISPA Berat" bahkan sampai seranganserangannya lebih lama (12). Status gizi tergantung dari asupan gizi dan kebutuhannya sehingga dibutuhkan asupan gizi yang seimbang untuk menghasilkan status gizi yang baik. Kebutuhan asupan gizi tergantung pada usia, jenis kelamin, aktivitas, berat badan dan tinggi badan (15).

Tidak adanya hubungan antara status gizi dengan kejadian ISPA di Puskesmas Samba Danum, mungkin karena status gizi bukanlah satu-satunya faktor penyebab kejadian ISPA. Kejadian ISPA pada balita dapat dipengaruhi oleh beberapa faktor, berdasarkan hasil croostab pada penelitian ini salah satunya yaitu status imunisasi lengkap diperoleh proporsi tertinggi pada pada status gizi baik yaitu sebesar $67.9 \%$ dengan kategori status imunisasi lengkap. Hal ini menunjukan bahwa meskipun balita yang berstatus gizi buruk, balita tetap mendapatkan imunisasi lengkap dari puskesmas, dan status gizi bukanlah merupakan faktor terjangkitnya penyakit ISPA.

\section{Status Imunisasi terhadap ISPA pada Balita}

Proporsi tertinggi ditemukan pada balita yang status imunisasinya tidak sebesar $62,4 \%$. Studi ini mendapatkan hasil adanya hubungan yang bermakna antara status imunisasi terhadap kejadian ISPA. Nilai PR status imunisasi terhadap kejadian ISPA adalah sebesar $1,519 \quad(1,075-2,147)$ yang berarti balita yang memiliki status imunisasinya tidak lengkap lebih berisiko 1,519 kali terkena ISPA dibandingkan dengan balita yang telah memiliki status imunisasi lengkap. Hasil tersebut sesuai dengan studi terdahulu yang juga menyatakan bahwa terdapat hubungan antara status imunisasi dengan kejadian penyakit ISPA pada balita (16)

Peraturan menteri Kesehatan RI No.

42 Tahun 2013 tentang Penyelenggaraan Imunisasi, Imunisasi adalah suatu upaya untuk meningkatkan kekebalan tubuh anak balita ataupun seseorang secara aktif terhadap suatu penyakit, sehingga apabila suatu saat terpajan dengan penyakit tersebut tidak akan mudah sakit ataupun hanya mengalami sakit ringan. Penyelenggaraan kegiatan Imunisasi adalah serangkain kegiatan dalam perencanaan, maupun pelaksanaan, monitoring dan evaluasi kegiatan imunisasi ISPA dapat dicegah dengan imunisasi dipteri, campak dan pertusis (6). Program kegiatan imunisasi ditujukan untuk menurunkan angka morbiditas dan mortalitas untuk penyakit-penyakit tertentu seperti Tuberkulosis, Dipteri, Pertusis, Tetanus, Hepatitis B, Polio dan Campak (6).

Program yang sudah dilakukan pihak puskesmas yaitu melakukan konseling pada setiap pengunjung yang datang ke puskesmas, pemberian imunisasi dasar dan imunisasi tambahan gratis kepada setiap balita. Program tersebut hampir berjalan dengan semestinya sesuai dengan program pemerintah peningkatan cakupan imunisasi layaknya harus ditingkatkan hingga mencapai angka 100\%, namun untuk cakupan imunisasi tersebut terhambat oleh vaksin yang terbatas, dan ibu yang masih enggan atau takut balitanya di vaksin, cakupan vaksin di puskesmas samba danum yaitu vaksin hepatitis $\mathrm{B}$, polio, $\mathrm{BCG}$, DPT, Hib, PCV.

Hal ini tentu saja harus diperbaiki dan ditingkatkan sebagaimana mestinya dengan cara mengelola jumlah vaksin agar cakupannya mencapai jumlah balita yang ada di wilayah kerja Puskesmas Samba Danum dan memotivasi ibu yang masih kurang informasi dan terpengaruh isu-isu negative tentang imunisasi, sehingga terbentuk kekebalan masyarakat yang tinggi. Kekebalan tersebut diperoleh dari cakupan imunisasi dasar dan lanjutan yang tinggi dan merata di seluruh wilayah untuk mencapai herd immunity.

\section{KESIMPULAN}

Penelitian ini menemukan proporsi cukup tinggi untuk ISPA pada balita yaitu $55.2 \%$. Terdapat hubungan yang bermakna antara umur dan status imunisasi dengan kejadian penyakit ISPA, tetapi tidak terdapat hubungan yang bermakna antara status gizi dengan kejadian penyakit ISPA pada balita.

\section{DAFTAR PUSTAKA}

1. Najma. EPIDEMIOLOGI PENYAKIT MENULAR. Jakarta: Jakarta: Trans Info Media; 2016.

2. Masriadi H. Epidemiologi Penyakit Menular. PT RajaGrafindo Jakarta. 2017;

3. UN-IGME. Levels and Trends in Child Mortality Report 2018 | United Nations 
Population Division | Department of Economic and Social Affairs. United Nations. 2018.

4. Kemenkes RI. Hasil Utama Riset Kesehatan Dasar Tahun 2018. Kementrian Kesehat Republik Indones. 2018;

5. DISHUBKOMINFO Provinsi Kalimantan Tengah. Angka penderita ISPA di Kalimantan Tengah yaitu mecapai 9.000 jiwa. 2018.

6. Kemenkes RI. Riset Kesehatan Dasar. Jakarta: Badan Penelitian dan Pengembangan Kesehatan Kementrian Kesehatan RI. 2013.

7. Suprihatin E. Hubungan Faktor-Faktor Dengan Kejadian ISPA pada Balita Di Puskesmas X Kota Bandung. J Keperawatan BSI. 2013;1(1).

8. Wiwik A. ANALISA FAKTORFAKTOR YANG MEMPENGARUHI TERJADINYA ISPA PADA BALITA DI DESA SIDOMUKTI KECAMATAN PLAOSAN KABUPATEN MAGETAN. STIKES BHAKTI HUSADA MULIA; 2018.

9. Sambominanga PS, Ismanto AY, Onibala F. Hubungan Pemberian Imunisasi dasar lengkap dengan Kejadian Penyakit ISPA berulang pada Balita di Puskesmas Ranotana Weru Kota Manado. J Keperawatan. 2014;2(2).

10. Malik I, Machfoedz I, Mahfud M. Cakupan Imunisasi Dasar dengan Kejadian ISPA pada Balita Usia 1-3 Tahun di Wilayah Puskesmas Wonosari 1 Kabupaten Gunungkidul. J Ners dan Kebidanan Indones. 2015;3(1):53-7.
11. Iskandar A, Tanuwijaya S, Yuniarti L. Hubungan jenis kelamin dan usia anak satu tahun sampai lima tahun dengan kejadian infeksi saluran pernapasan akut (ISPA). Glob Med Heal Commun. 2015;3(1):1-6.

12. Maryunani A. Ilmu Kesehatan Anak dalam Kebidanan. Jakarta: Trans Info Media.; 2010.

13. Kemenkes RI. Indikator Indonesia Sehat 2010. Regulation. 2010;

14. Akbar. Hubungan faktor determinan penyakit infeksi saluran pernapasan akut (ispa) dengan kejadian inpeksi saluran pernafasan akut (ispa) pneumonia pada balita di wilayah kerja puskesmas cipaku kabupaten ciamis tahun 2020. https://jurnal.unigal.ac.id/index.php/JK G/article/view/4532. 2020;

15. Kementerian Kesehatan Repulik Indonesia. Buku Saku Pemantauan Status Gizi Tahun 2017. 2017.

16. Rahman. Hubungan pemberian asi eksklusif dengan kejadian penyakit infeksi saluran pernafasan akut pada anak balita di wilayah kerja puskesmas managaisaki.

http://jurnal.untad.ac.id/jurnal/index.ph $\mathrm{p} /$ HealthyTadulako/article/view/5732. 2013; 